\title{
Térfogatalapú haemostasistartalékok vérmentes májtranszplantációk során
}

\author{
Rengeiné Kiss Tímea PhD drd. ${ }^{1}$ - Smudla Anikó dr. ${ }^{1}$ - Dinya Elek dr. ${ }^{2}$ \\ Kóbori László dr. ${ }^{1}$ - Piros László dr. ${ }^{1}$ - Szabó József dr. ${ }^{1}$ \\ Máthé Zoltán dr. ${ }^{3}$. Illés Sándor dr. ${ }^{1}$ - Mándli Tamás dr. ${ }^{1}$. Szabó Tamás dr. ${ }^{1}$ \\ Szabó Mónika dr. ${ }^{1}$. Tóth Szabolcs dr. ${ }^{1}$. Tózsér Gellért dr. ${ }^{1}$. Túri Csaba dr. ${ }^{1}$ \\ Füle Balázs dr. ${ }^{1}$ - Kanizsai Péter dr. ${ }^{4^{*}}$ - Fazakas János dr. ${ }^{1^{*}}$ \\ ${ }^{1}$ Semmelweis Egyetem, Általános Orvostudományi Kar, Transzplantációs és Sebészeti Klinika, Budapest \\ ${ }^{2}$ Semmelweis Egyetem, Egészségügyi Közszolgálati Kar, Budapest \\ ${ }^{3}$ Medical University Graz, Department of Surgery, Division of Transplant Surgery, Graz, Ausztria \\ ${ }^{4}$ Pécsi Tudományegyetem, Általános Orvostudományi Kar, Sürgősségi Orvostani Tanszék, Pécs
}

\begin{abstract}
Bevezetés: A májtranszplantáció során a haemostasis a hagyományos alvadásifaktor-szintekkel és a viszkoelasztikus tesztekkel monitorizálható, nem szokványos megközelítése a coagulatiósfaktor-specifikus vérveszteség dinamikus követése.

Célkitüzés: Kutatásunk célja az alvadásifaktor-specifikus vérveszteség alapján kiszámolt térfogati tartalékok vizsgálata, a vér- és faktorkészítmény-mentes májtranszplantáció első 48 órájában a Child-Pugh-score tükrében is.

Módszer: 59, vér- és faktorkészítményt nem igénylő, májtranszplantált beteg hagyományos alvadásifaktor-szintjeit, viszkoelasztikus paramétereit és faktorspecifikus vérveszteségeit elemeztük Gross-metódus segítségével, kiindulási és „coagulopathiás” triggerszintek alapján. A haemostasistartalékokat Child-Pugh-osztályozás szerint is összehasonlítottuk. A hagyományos laboratóriumi vizsgálatok és a faktorspecifikus térfogati tartalékok kiszámítása a májtranszplantáció előtt (T1), végén (T2) és 12-24-48 órával utána (T3-T4-T5) történt. A viszkoelasztikus tesztek eredményeit a májtranszplantáció előtt (T1) és végén (T2) rögzítettük.

Eredmények: A műtét végére az alapszintről a fibrinogén 1,2 g/l-rel, míg a protrombin és az V-ös, a VII-es és a X-es faktor 26-40\%-kal csökkent. A posztoperatív időszakban a fibrinogénszint 0,9 g/l-rel (T2-T4, p<0,001), míg a II-es, az V-ös, a VII-es és a X-es faktor szintje 12-30\%-kal emelkedett (T3-T5, p<0,001). A viszkoelasztikus tesztek paraméterei a normáltartományban maradtak a mútét végén is (T1-T2). A haemostasis-össztartalék 61\%-os csökkenést mutatott az operáció végére $(\mathrm{p}<0,001)$, azonban a posztoperatív második napra elérte a kiindulási érték $88 \%$-át. A kiindulási tartalékok a Child-Pugh A csoporthoz viszonyítva a dekompenzált Child-Pugh B és C csoportnál 3641\%-kal alacsonyabbak voltak, a 48. órára azonban a különbség már nem volt szignifikáns.

Következtetés: A haemostasis térfogatalapú megközelítése kiegészíti a hagyományos laboratóriumi vizsgálatokat és a viszkoelasztikus teszteket, mivel dinamikusan jelzi a haemostasis aktuális tartalékát faktoronként, és a „leggyengébb láncszemet" mutatja meg a rendszerben.
\end{abstract}

Orv Hetil. 2020; 161(7): 252-262.

Kulcsszavak: vérmentes májtranszplantáció, haemostasis, alvadási faktor

\section{Volume-based haemostasis reserves in blood product free liver transplantations}

Introduction: During liver transplantation, haemostasis is typically assessed by means of standard laboratory tests and viscoelastic tests, while dynamic monitoring of coagulation factor specific blood losses is an unusual, yet established approach.

Aim: Our aim was to evaluate the volume-based haemostasis reserves in blood product free liver transplants in the first perioperative 48 hours, in association with the Child-Pugh score.

Method: Data of 59 blood product free liver transplanted patients' coagulation factor levels, viscoelastic parameters and coagulation factor specific blood losses according to Gross methodological, baseline and 'coagulopathic' trigger levels were analysed. The haemostasis reserves were estimated according to the Child-Pugh classification. Labora- 
tory tests and the calculation of haemostasis reserves were carried out before liver transplantation (T1), at the end of the surgery (T2) and also 12-24-48 hours postoperatively (T3-T4-T5). The viscoelastic tests were performed before liver transplantation (T1) and at the end of the surgery (T2).

Results: Fibrinogen levels decreased by $1.2 \mathrm{~g} / \mathrm{L}$. Factor II, V, VII, X levels decreased by 26-40\%. From T2 to T4, fibrinogen increased by $0.9 \pm 0.6 \mathrm{~g} / \mathrm{L}$ over $24 \mathrm{~h}(\mathrm{p}<0.001)$. Factor II, V, VII, X levels increased by $12-30 \%$ between $\mathrm{T} 3$ to $\mathrm{T} 5(\mathrm{p}<0.001)$. The viscoelastic parameters remained in the normal range during liver transplantation $(\mathrm{T} 1-\mathrm{T} 2)$. Haemostasis reserves decreased by $61 \%$ at the end of surgery $(\mathrm{p}<0.001)$, but reached $88 \%$ of the preoperative value on the second postoperative day. The initial reserves of Child B and C groups were 36-41\% lower than Child A, nevertheless, these differences were not significant at 48 hours.

Conclusion: The volume-based haemostasis approach supplements the standard laboratory and viscoelastic tests. This unusual approach dynamically indicates the actual reserve of haemostasis and shows the 'weakest link' within the system.

Keywords: bloodless transplantation, haemostasis, coagulation factor

Rengeiné Kiss T, Smudla A, Dinya E, Kóbori L, Piros L, Szabó J, Máthé Z, Illés S, Mándli T, Szabó T, Szabó M, Tóth Sz, Tőzsér G, Túri Cs, Füle B, Kanizsai P, Fazakas J. [Volume-based haemostasis reserves in blood product free liver transplantations]. Orv Hetil. 2020; 161(7): 252-262.

(Beérkezett: 2019. október 2.; elfogadva: 2019. október 30.)

\section{Rövidítések}

ALT = alanin-aminotranszferáz; AST = aszpartát-aminotranszferáz; AT-III = antitrombin-III; BMI = (body mass index $)$ test tömegindex; Child-Pugh-score = végstádiumú májbetegségek stádiumbeosztása; FIV = kalcium; CI $=($ confidence interval $)$ konfidenciaintervallum; $\mathrm{CVP}=($ central venous pressure $)$ cent rális vénás nyomás; HT = térfogatalapú haemostasis-össztartalék; Ly 60 = százalékos fibrinolízis 60 perc alatt; $\mathrm{MA}=$ maximális amplitúdó; MELD = (model for end-stage liver disease $)$ végstádiumú májbetegségek matematikai modellje; OLTx = (orthotopic liver transplantation) ortotopikus májátültetés; $\mathrm{R}=$ reakcióidö; $r$-ANOVA = (repeated analysis of variance $)$ ismételt varianciaanalízis; $S D$ = standard deviáció; $S E$ TUKEB = a Semmelweis Egyetem Tudományos és Kutatásetikai Bizottsága; SOFA-score $=($ sequential organ failure assessment $)$ a szervi elégtelenség súlyossági pontrendszere; $\mathrm{Tl}=$ májtranszplantáció előtt; T2 = mûtét végén; T3 = a májátültetés után 12 órával; T4 = a májátültetés után 24 órával; T5 = a májátülttetés után 48 órával; TEG = trombelasztográfia (viszkoelasztikus teszt)

Az ortotopikus májátültetés (OLTx) során kialakuló jelentős vérveszteség oka lehet sebészeti vérzés vagy microvascularis coagulopathia. A sebészeti vérzés hátterében korábbi hasi műtétek miatti összenövések és a portalis hypertensióból adódó vascularis tényezók állnak, amelyek a haemostasistartalékoktól függően diffúz vérzés kialakulásához is vezethetnek [1-3]. A coagulopathiás vérzés kockázatát számos irányelv alacsony tartalékban -l g/l-nél kevesebb fibrinogén- és/vagy 30\%-nál alacsonyabb véralvadásifaktor-szintekben - határozza meg $[4,5]$. A viszkoelasztikus tesztekkel komplex képet kapunk a haemostasisról, mivel a vér teljes alvadását vizsgálja [6-8].

A megengedhető vérveszteség elvét évtizedek óta használjuk a hemoglobin-határértékek meghatározására az anaemiás hypoxia szemszögéből. A módszer segít egyénileg megbecsülni azt a térfogatban meghatározott vérmennyiséget, amelynek az elvesztése után az oxigénadósság kialakulásának veszélye magas $[9,10]$. Felmerül, hogy ha a megengedhetô vérveszteség elvét az alvadási faktorok esetében alkalmazzuk, akkor térfogatban is meghatározható az a vérmennyiség, amelynek elvesztése során coagulopathiás, diffúz vérzés kialakulása várható.

Kutatásunk fö célja az alvadási faktorok, a viszkoelasztikus tesztek mellett a coagulatiospecifikus vérveszteség alapján kiszámolt térfogati tartalékok kinetikájának követése volt. A perioperatív haemostasist befolyásoló tényező́k minimalizálása érdekében a vizsgálatot első lépésben vérkészítmény- és faktorkészítmény-mentes májtranszplantációknál tartottuk érdemesnek elvégezni.

\section{Betegek és módszer}

A Transzplantációs és Sebészeti Klinikán 2015 és 2018 között prospektív adatfeldolgozást végeztünk vérkészítménymentes májátültetéseket illetően. A vizsgálatba 175, vérkészítménymentes májtranszplantációból 59 beteget vontunk be, akiknél nem volt szükség alvadásifaktor-pótlásra sem. Kizárási kritérium volt a 18 év alatti életkor, illetve az akut májelégtelenség.

A májtranszplantációk vena cava szegmens/crossclamp technikával, venovenosus bypass nélkül történtek, a graftot átlagosan $200-300 \mathrm{ml}$ vérrel átmosva. A betegek az intézményi protokollnak megfelelően azonos anesztéziában részesültek. A posztoperatív időszakban az összes májátültetettet az intenzív osztályon, standardizált protokoll alapján kezeltük. Vizsgáltuk a betegek demográfiai adatait, a transzplantációspecifikus súlyossági pontszámokat, a hideg- és melegischaemiás időt. A szupportív terápiás igény mellett a szervi diszfunkció mértékét és a morbiditási mutatókat is rögzítettük (1. ábra). 


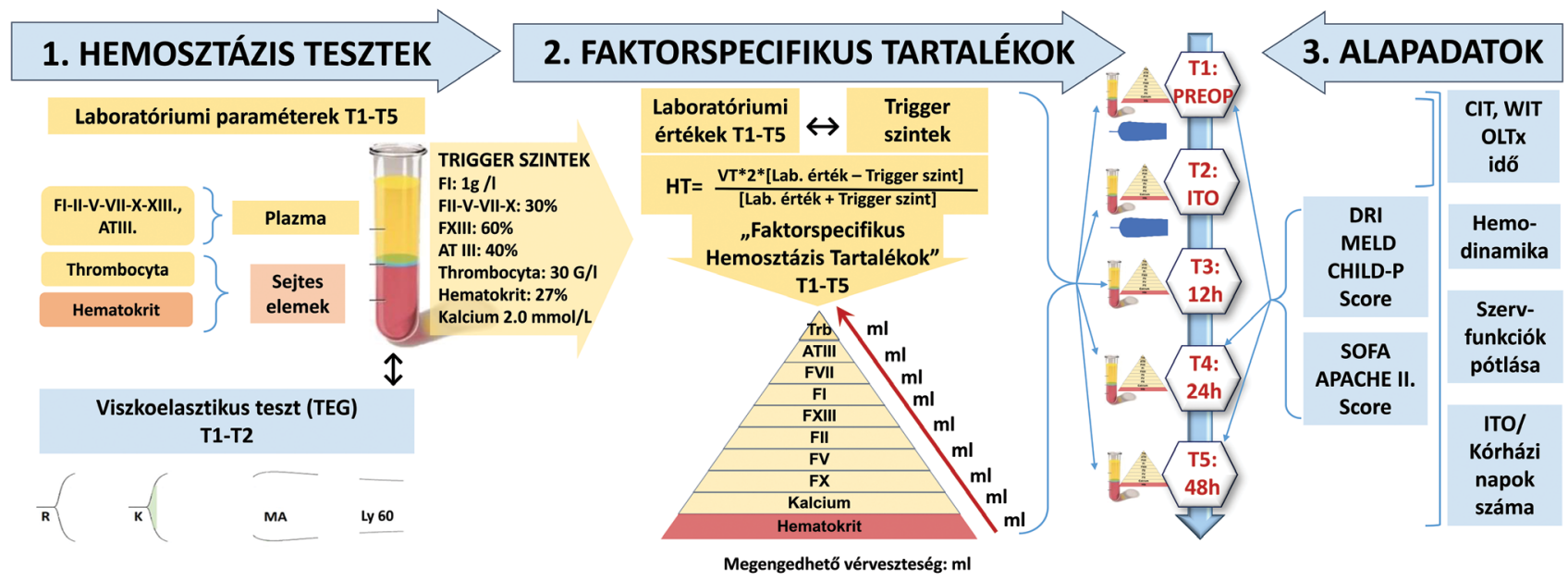

(4) Semmelweis Egyetem TUKEB No.: 149/2016 ClinicalTrials.gov ID: NCT03555383

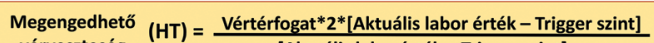

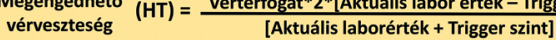

\begin{tabular}{l|l} 
1. ábra & Kutatási protokoll
\end{tabular}

Konvencionális haemostasisvizsgálatok elvégzése májtranszplantáció előtt (T1), végén (T2), 12-24-48 órával OLTx után (T3-T4-T5), TEG-analízisek (T1-T2). A faktorspecifikus megengedhető vérveszteségek kiszámítása az aktuális laboratóriumi paraméterek és a coagulopathiás triggerszintek (FI: 1 g/l, FII-V-VII-X: 30\%, F XIII: 60\%, thrombocyta: 30 G/l, AT-III: 40\%, hematokrit: 27\%, kalcium 2,0 mmol/l) segítségével a Gross matematikai képlet alapján. Demográfiai adatok, a transzplantációspecifikus súlyossági pontszámok, a hideg- és melegischaemiás idők, a mútéti adatok, szupportív terápiás igény (lélegeztetés, keringéstámogatás) rögzítése

APACHE II. = betegségsúlyossági pontrendszer; AT-III = antitrombin-III; Child-Pugh-score = végstádiumú májbetegségek stádiumbeosztása; CIT = hidegischaemiás idő; DRI = donorrizikó-index; FI = I-es faktor (fibrinogén); FII = II-es faktor (protrombin); FV = V-ös faktor (proakcelerin - labilis faktor); FVII = VII-es faktor; FX = X-es faktor; FXIII = XIII-as faktor; HT = térfogatalapú haemostasis-össztartalék; ITO = intenzív terápiás osztály; $\mathrm{K}$ = kinetikai idő; Ly 60 = százalékos fibrinolízis 60 perc alatt; MA = maximális amplitúdó; MELD = végstádiumú májbetegségek matematikai modellje; OLTx $=$ ortotopikus májátültetés; $\mathrm{R}=$ reakcióidő; SOFA-score $=$ szervi elégtelenség súlyossági pontrendszere; Tl $=$ májtranszplantáció előtt; $\mathrm{T} 2=$ mútét végén; T3 = a májátültetés után 12 órával; $\mathrm{T} 4=$ a májátültetés után 24 órával; $\mathrm{T} 5=\mathrm{a}$ májátültetés után 48 órával; TEG $=$ trombelasztográfia; TRB = thrombocytaszuszpenzió; VT = vértérfogat; WIT = melegischaemiás idő

A betegek hemodinamikai megfigyelését transpulmonalis thermodilutiós technikával $\left(\mathrm{PiCCO}_{2}\right.$ Monitor, Getinge/Pulsion Medical Systems, Feldkirchen, Németország) végeztük. A megbecsült intraoperatív vérveszteséget az eltávolított májból származó vérveszteségből, a graft prezervációs oldatának saját vérrel történő kiöblítéséből származó veszteségéből és az elkerülhetetlen sebészeti vérveszteség (sebészeti szívórendszerrel összegyưjjtött vér és az átitatott törlők száma) alapján számítottuk ki [11]. Az intraoperatív folyadékegyensúlyt a beadott krisztalloid és kolloid oldatok, valamint a számolt vérveszteség, a vizeletürítés és a megbecsült perspiratio insensibilis $(2 \mathrm{ml} / \mathrm{kg} /$ óra $)$ különbsége alapján határoztuk meg. Normovolaemia esetén a graft reperfusiója után az ischaemiás reperfusiós hypotoniát vasopressorral kezeltük. A tolerálható hypovolaemia/vasoplegia fenntartása érdekében azonban esetenként folyadékpótlást és vasoactiv gyógyszert együttesen is alkalmaztunk, így a kezelést a beteg pillanatnyi haemostasisához és hemodinamikai állapotához igazítottuk. A mưtét után a posztoperatív „nulla” folyadékegyenleget céloztuk meg, szorosan követve az óránkénti veszteségeket és a folyadékbevitelt. Hypocalcaemia esetén a kalciumpótlást az intézményi protokollnak megfelelően folyamatos infúziós pumpán át, illetve igény szerint bolusban adagoltuk.
A vizsgált alvadási faktorok, a hematokrit- és thrombocytaszint-mérésekhez Sysmex CS 2000i, Sysmex XN1000 és Siemens Dimension ${ }^{\circledR}$ RxL Max $^{\circledR}$ Integrated Chemistry System mûszereket használtunk. A laboratóriumi vizsgálatokat előre meghatározott időpontokban végeztük: májtranszplantáció előtt ( $\mathrm{Tl})$, a mütét végén (T2), majd 12 órával (T3), 24 órával (T4) és 48 órával (T5) a májátültetés után.

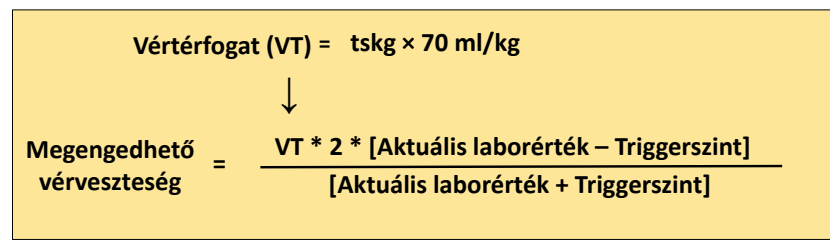

2. ábra

A vértérfogat számítási képlete és a megengedhető vérveszteség számítási képlete a Gross-metódus alapján

A coagulopathiás triggerszintek: FI: $1 \mathrm{~g} / \mathrm{l}$, FII-V-VII-X: 30\%, FXIII: $60 \%$, thrombocyta: $30 \mathrm{G} / \mathrm{l}$, AT-III: $40 \%$, hematokrit: $27 \%$, kalcium 2,0 $\mathrm{mmol} / \mathrm{l}$; laboratóriumi értékek: aktuálisan mért faktorszintek (Tl-T5)

AT-III $=$ antitrombin-III; FI = I-es faktor $(($ fibrinogén $) ; \mathrm{FII}=$ II-es faktor (protrombin); FV = V-ös faktor (proakcelerin - labilis faktor); FVII = VII-es faktor; FX = X-es faktor; FXIII = XIIIas faktor; $\mathrm{T} 1=$ májtranszplantáció elött; $\mathrm{T} 2=$ mútét végén; T3 = a májátültetés után 12 órával; T4 = a májátültetés után 24 órával; $\mathrm{T} 5=$ a májátültetés után 48 órával; $\mathrm{VT}=$ vértérfogat 

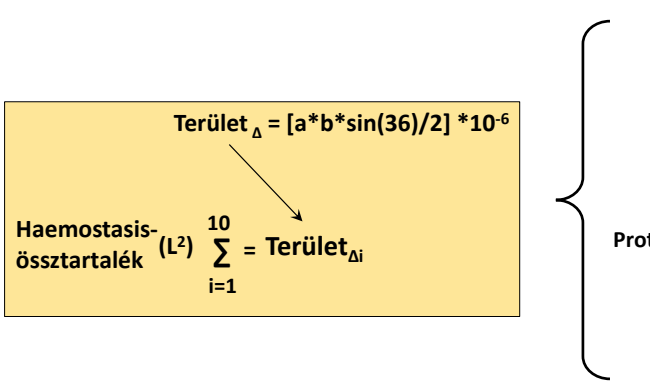

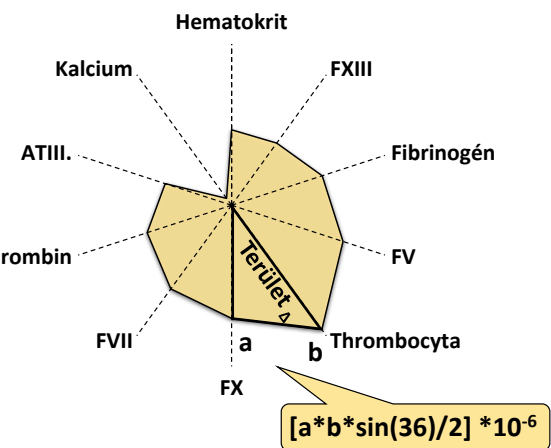

3. ábra

A haemostasis-össztartalék kiszámítása

AT-III = antitrombin-III; FV = V-ös faktor (proakcelerin - labilis faktor); FVII = VII-es faktor; FX = X-es faktor; FXIII = XIII-as faktor; L ${ }^{2}=$ a térfogatalapú haemostasis-össztartalék sugárdiagram görbe alatti területének számítása trigonometrikus területképlet alapján

A trombelasztográfiás (TEG) vizsgálatokhoz a TEG 5000 Thrombelastograph Hemostasis Analyzer System analizátort (Haemonetics Corporation, Braintree, MA, Amerikai Egyesült Államok [USA]) használtuk, standard kaolinpróbával a transzplantáció előtt (T1) és után (T2). A TEG-paraméterek közül a következóket rögzítettük: reakcióidő $(\mathrm{R})$, maximális amplitúdó (MA), százalékos fibrinolízis 60 perc alatt (Ly 60) (1. ábra).

\section{Az alvadásifaktor-specifikus megengedhető vérveszteség módszertana}

Az alvadásifaktor-specifikus megengedhető vérveszteséget öt időpontban (T1-T5) a Gross matematikai képlet alapján számoltuk ki, a mért laboratóriumi paraméterek aktuális szintje és a coagulopathiás triggerszintek segítségével, és milliliterben fejeztük ki őket [9] (2. ábra).

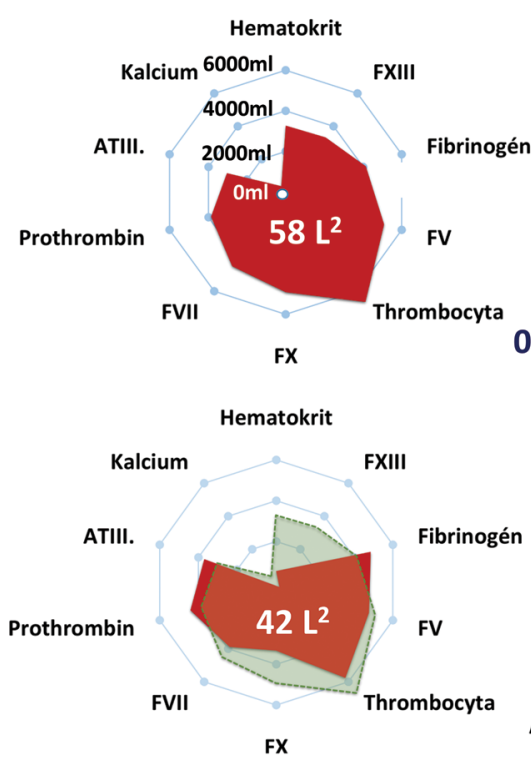

$n=59$
Prothrombin

$$
\text { Prothrombin }
$$

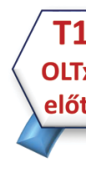

-48 óra
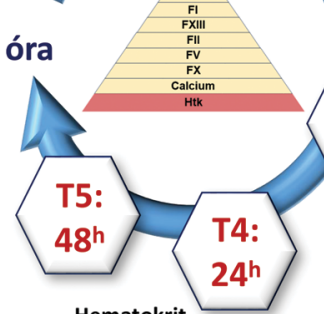

T3

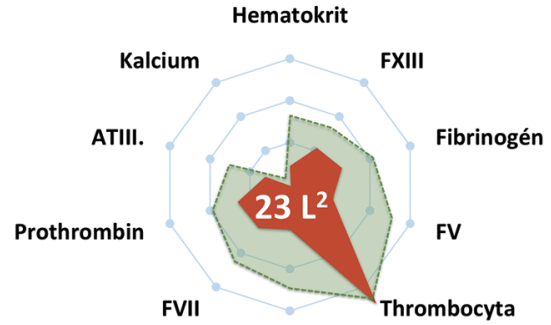

FX

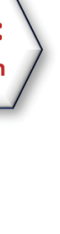
Kalcium FXIII Prothrombin

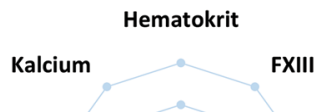

ATIII.

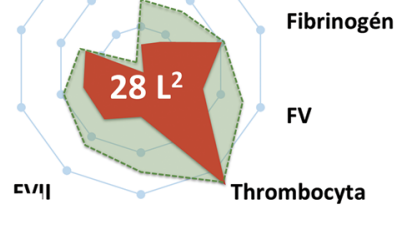

FV Thrombocyta
Aktuális HT (ml)
Kiindulási HT (ml)

4. ábra $\quad$ Térfogatalapú faktorspecifikus haemostasistartalékok májtranszplantáció előtt (T1), végén (T2), 12-24-48 órával utána (T3-T4-T5)

A faktorspecifikus megengedhető vérveszteségek átlagértékeit a sugárdiagram szemlélteti. A legkisebb tartalékot a sugár közepe jelzi ( 0 ml), majd a sugár rádiuszán kifelé haladva paraméterenként piros jelzéssel az aktuális, zöld jelzéssel a preoperatív kiindulási térfogat látható milliliterben kifejezve. A sugárdiagram görbe alatti területe jelzi a térfogatalapú haemostasis-össztartalékot $\left(\mathrm{L}^{2}\right)$

AT-III $=$ antitrombin-III; FV = V-ös faktor (proakcelerin - labilis faktor); FVII $=$ VII-es faktor; FX $=$ X-es faktor; FXIII $=$ XIII-as faktor; HT $=$ térfogatalapú haemostasis-össztartalék; $\mathrm{L}^{2}=$ a térfogatalapú haemostasis-össztartalék sugárdiagram görbe alatti területének számítása trigonometrikus területképlet alapján; $\mathrm{Tl}=$ májtranszplantáció előtt; $\mathrm{T} 2=$ mútét végén; $\mathrm{T} 3=$ a májátültetés után 12 órával; $\mathrm{T} 4=\mathrm{a}$ májátültetés után 24 órával; $\mathrm{T} 5=\mathrm{a}$ májátültetés után 48 órával 
A faktorspecifikus megengedhető vérveszteségeket együttesen térfogatalapú haemostasis-össztartaléknak (HT) neveztük el, és sugárdiagram segítségével ábrázoltuk (3. ábra).

A sugárdiagram görbe alatti területét a tíz faktor által alkotott tíz különböző háromszög területének összegéból kaptuk meg, és L ${ }^{2}$-ben fejeztük ki. Az egyes háromszögek területét trigonometrikus területképlet alapján számítottuk, ahol „a” és „b” az adott háromszöget képező, egymással szomszédos faktorok értéke (3. ábra). A haemostasis-össztartalékot Child-Pugh-osztályozás alapján is elemeztük.

\section{Statisztikai analízis}

Az eredmények értékelésekor az átlagot, a standard deviációt (SD) és a konfidenciaintervallumot (CI) az átlag \pm standard deviációjában fejeztük ki. Az adatok normalitását a Shapiro-Wilk-teszt alkalmazásával ellenóriztük. Amennyiben az adatok nem normális eloszlásúak voltak, Levene-féle teszt segítségével értékeltük az eltérések homogenitását. A változókat ismételt varianciaanalízissel (r-ANOVA) hasonlítottuk össze, és ahol szükséges volt, ott Tukey-korrekciót alkalmaztunk a többszörös összehasonlításra. Pearson-féle khi-négyzet-tesztet $\left(\chi^{2}\right)$ vagy
Fisher-féle egzakt tesztet alkalmaztunk a kategorikus adatok halmazaira.

Az elemzés kétoldalas volt, $\alpha=0,05$ szignifikanciaszinttel. Minden statisztikai elemzéshez az SPSS 25.0 (IBM Corporation, Armonk, NY, USA) szoftvercsomagot használtunk. Az offline adatelemzéshez és a grafikonok létrehozásához a Microsoft Excel 2016-os szoftvercsomagot (Microsoft Corporation, Redmond, WA, USA) használtuk.

\section{Eredmények}

A demográfiai adatok, a májátültetés leggyakoribb indikációi, a súlyossági score-ok, a hideg- és melegischaemiás idő, az intenzív osztályos és a kórházi tartózkodási idő az 1. táblázatban látható. A vizsgált betegek középkorúak voltak, kissé túlsúlyos tartományú BMI-vel, alacsony MELD-pontszámmal és változó Child-Pugh-értékekkel. A keringéstámogatási igény a betegek $87,5 \%$-ánál megszûnt a mútét után 24 órán belül, viszont 7 beteg 48 órát meghaladóan is vasopressorterápiát igényelt. Minden transzplantáltat 12 órával a májátültetés után extubáltunk (1. táblázat). A megbecsült intraoperatív vérveszteség $1174 \pm 490 \mathrm{ml}$, az összbevitel $2800 \pm 1051$ $\mathrm{ml}$, az intraoperatív pozitív folyadékegyensúly pedig 611 $\pm 896 \mathrm{ml}$ volt. A posztoperatív drénhozam (vérveszteség

1. táblázat | Demográfiai jellemzők

\begin{tabular}{|c|c|c|c|c|c|}
\hline \multicolumn{6}{|c|}{ Demográfiai adatok $(\mathrm{n}=59)$} \\
\hline Nő/Férfi & & $37 / 22$ & \multirow{8}{*}{ Etiológia } & Vírusos (HBV/HCV) & $1 / 10$ \\
\hline \multirow[t]{2}{*}{ Életkor } & \multirow[t]{2}{*}{ (év) } & \multirow[t]{2}{*}{$47,6 \pm 14$ (CI: 44-51) } & & $\mathrm{ALD} / \mathrm{AIH}$ & $8 / 6$ \\
\hline & & & & $\mathrm{PBC}$ & 2 \\
\hline \multirow{3}{*}{ Testsúly } & \multirow{3}{*}{$(\mathrm{kg})$} & \multirow{3}{*}{$79 \pm 18$ (CI: 75-84) } & & PSC & 23 \\
\hline & & & & Polycystás (PLD) & 3 \\
\hline & & & & Budd-Chiari-szindróma & 1 \\
\hline \multirow[t]{2}{*}{ BMI } & \multirow[t]{2}{*}{$\mathrm{kg} / \mathrm{m}^{2}$} & \multirow[t]{2}{*}{$26 \pm 5$ (CI: 24-27) } & & Caroli-szindróma & 2 \\
\hline & & & & $\mathrm{CF} /$ cryptogen & $1 / 2$ \\
\hline \multicolumn{2}{|l|}{ OLTx } & & \multicolumn{3}{|l|}{ SCORE-ok } \\
\hline \multicolumn{2}{|l|}{ DRI } & $1,5 \pm 0,3(\mathrm{CI}: 1,4-1,5)$ & \multicolumn{2}{|l|}{ MELD-score } & $11 \pm 3(\mathrm{CI}: 10-12)$ \\
\hline CIT & (perc) & $407 \pm 111(\mathrm{CI}: 378-436)$ & \multirow{2}{*}{ Child-Pugh-score } & \multirow[t]{2}{*}{$\mathrm{A} / \mathrm{B} / \mathrm{C}$} & \multirow[t]{2}{*}{$23 / 26 / 10$} \\
\hline WIT & (perc) & $41 \pm 19(20-136)$ & & & \\
\hline Mütéti idő & $($ perc $)$ & $233 \pm 64(\mathrm{CI}: 216-249)$ & \multirow{3}{*}{ SOFA-score } & Perioperatív & $5 \pm 2(\mathrm{CI}: 5-6)$ \\
\hline \multicolumn{3}{|l|}{ Szupportív terápia } & & 24. óra & $6 \pm 2(\mathrm{CI}: 6-7)$ \\
\hline Lélegeztetési idő & (óra) & $7,5 \pm 5,8(\mathrm{CI}: 6-9)$ & & 48. óra & $6 \pm 2(\mathrm{CI}: 6-7)$ \\
\hline Keringéstámogatás & (óra) & $10 \pm 11(\mathrm{CI}: 7,4-13,2)$ & \multirow{3}{*}{ APACHE II.-score } & Perioperatív & $16 \pm 5(\mathrm{CI}: 15-18)$ \\
\hline ITO-napok & (nap) & $5 \pm 6,4$ (CI: $3,3-6,7)$ & & 24. óra & $13 \pm 3$ (CI: $12-14)$ \\
\hline Kórházi napok & (nap) & $18,5 \pm 10,8(\mathrm{CI}: 16-21)$ & & 48. óra & $14 \pm 4(\mathrm{CI}: 13-15)$ \\
\hline
\end{tabular}

$\mathrm{AIH}=$ autoimmun hepatitis; $\mathrm{ALD}=$ alkoholos májbetegség; APACHE II. = betegségsúlyossági pontrendszer; $\mathrm{BMI}=$ testtömegindex; CF = cystás fibrosis; Child-Pugh-score = végstádiumú májbetegségek stádiumbeosztása CI = konfidenciaintervallum; CIT = hidegischaemiás idő; DRI = donorrizikó-index; $\mathrm{HBV}=$ hepatitis B-vírus; $\mathrm{HCV}=$ hepatitis $\mathrm{C}$-vírus; ITO = intenzív terápiás osztály; MELD = végstádiumú májbetegségek matematikai modellje; OLTx = ortotopikus májátültetés; PBC = primer biliaris cirrhosis; PLD = polycystás májbetegség; PSC = primer szklerotizáló cholangitis; SOFA-score = a szervi elégtelenség súlyossági pontrendszere; WIT = melegischaemiás idő 
2. táblázat |Coagulatiósfaktor-szintek és térfogatalapú faktorspecifikus haemostasistartalékok májtranszplantáció előtt (T1), végén (T2), OLTx után 12-24-48 órával (T3-T4-T5). A változókat a mérési időpontok között ismétléses varianciaanalízissel (Friedman-ANOVA) hasonlítottuk össze; az elemzés kétoldalas volt, $\alpha=0,05$ szignifikanciaszinttel

\begin{tabular}{|c|c|c|c|c|c|c|c|}
\hline \multicolumn{8}{|c|}{ Coagulatiósfaktor-szintek } \\
\hline \multirow[t]{2}{*}{ Paraméter } & \multirow[t]{2}{*}{ Egység } & Tl (OLTx előtt) & T2 (OLTx után) & T3 (12. óra) & T4 (24. óra) & T5 (48. óra) & \multirow[t]{2}{*}{ p-érték } \\
\hline & & átlag \pm szórás & átlag \pm szórás & átlag \pm szórás & átlag \pm szórás & átlag \pm szórás & \\
\hline Fibrinogén (FI) & $\mathrm{g} / 1$ & $\begin{array}{c}2,9 \pm 1 \\
(\mathrm{CI}: 2,7-3,2)\end{array}$ & $\begin{array}{c}1,7 \pm 0,6 \\
(\mathrm{CI}: 1,6-1,8)\end{array}$ & $\begin{array}{c}2,3 \pm 0,4 \\
(\mathrm{CI}: 2,1-2,4)\end{array}$ & $\begin{array}{c}2,6 \pm 0,7 \\
(\mathrm{CI}: 2,4-2,8)\end{array}$ & $\begin{array}{c}2,8 \pm 0,7 \\
(\mathrm{CI}: 2,6-3)\end{array}$ & $>0,001$ \\
\hline Protrombin (FII) & $\%$ & $\begin{array}{c}77 \pm 14 \\
(\mathrm{CI}: 73-82)\end{array}$ & $\begin{array}{c}51 \pm 19 \\
(\mathrm{CI}: 47-55)\end{array}$ & $\begin{array}{c}54 \pm 14 \\
(\mathrm{CI}: 50-57)\end{array}$ & $\begin{array}{c}59 \pm 18 \\
(\mathrm{CI}: 54-63)\end{array}$ & $\begin{array}{c}74 \pm 16 \\
(\mathrm{CI}: 69-78)\end{array}$ & $>0,001$ \\
\hline Kalcium (FIV) & $\mathrm{mmol} / \mathrm{l}$ & $\begin{array}{c}2,2 \pm 0,1 \\
(\mathrm{CI}: 2,2-2,3)\end{array}$ & $\begin{array}{l}2,07 \pm 0,3 \\
(\mathrm{CI}: 2-2,1)\end{array}$ & $\begin{array}{l}2,01 \pm 0,2 \\
(\mathrm{CI}: 1,9-2)\end{array}$ & $\begin{array}{c}1,9 \pm 0,2 \\
(\mathrm{CI}: 1,9-2)\end{array}$ & $\begin{array}{c}2 \pm 0,1 \\
(\mathrm{CI}: 1,9-2)\end{array}$ & $>0,001$ \\
\hline FV & $\%$ & $\begin{array}{c}90 \pm 28 \\
(\mathrm{CI}: 83-98)\end{array}$ & $\begin{array}{c}50 \pm 22 \\
(\mathrm{CI}: 44-55)\end{array}$ & $\begin{array}{c}59 \pm 26 \\
(\mathrm{CI}: 53-66)\end{array}$ & $\begin{array}{c}77 \pm 26 \\
(\mathrm{CI}: 70-83)\end{array}$ & $\begin{array}{c}91 \pm 27 \\
(\mathrm{CI}: 84-98)\end{array}$ & $>0,001$ \\
\hline FVII & $\%$ & $\begin{array}{c}82 \pm 32 \\
(\mathrm{CI}: 73-90)\end{array}$ & $\begin{array}{c}53 \pm 21 \\
(\mathrm{CI}: 47-58)\end{array}$ & $\begin{array}{c}59 \pm 26 \\
(\mathrm{CI}: 53-66)\end{array}$ & $\begin{array}{c}67 \pm 26 \\
(\mathrm{CI}: 61-74)\end{array}$ & $\begin{array}{c}71 \pm 27 \\
(\mathrm{CI}: 64-78)\end{array}$ & $>0,001$ \\
\hline FX & $\%$ & $\begin{array}{c}88 \pm 32 \\
(\mathrm{CI}: 80-96)\end{array}$ & $\begin{array}{c}49 \pm 20 \\
(\mathrm{CI}: 43-53)\end{array}$ & $\begin{array}{c}50 \pm 19 \\
(\mathrm{CI}: 45-55)\end{array}$ & $\begin{array}{c}54 \pm 14 \\
(\mathrm{CI}: 50-57)\end{array}$ & $\begin{array}{c}62 \pm 17 \\
(\mathrm{CI}: 58-67)\end{array}$ & $>0,001$ \\
\hline FXIII & $\%$ & $\begin{array}{c}121 \pm 34 \\
(\mathrm{CI}: 112-130)\end{array}$ & $\begin{array}{c}95 \pm 27 \\
(\mathrm{CI}: 87-101)\end{array}$ & $\begin{array}{c}84 \pm 22 \\
(\mathrm{CI}: 78-90)\end{array}$ & $\begin{array}{c}73 \pm 20 \\
(\mathrm{CI}: 67-78)\end{array}$ & $\begin{array}{c}74 \pm 19 \\
(\mathrm{CI}: 69-79)\end{array}$ & $>0,001$ \\
\hline AT-III & $\%$ & $\begin{array}{c}90 \pm 31 \\
(\mathrm{CI}: 82-98)\end{array}$ & $\begin{array}{c}55 \pm 21 \\
(\mathrm{CI}: 49-60)\end{array}$ & $\begin{array}{c}72 \pm 22 \\
(\mathrm{CI}: 66-78)\end{array}$ & $\begin{array}{c}83 \pm 18 \\
(\mathrm{CI}: 79-87)\end{array}$ & $\begin{array}{c}86 \pm 15 \\
(\mathrm{CI}: 82-89)\end{array}$ & $>0,001$ \\
\hline Hematokrit & $\%$ & $\begin{array}{c}38 \pm 3 \\
(\mathrm{CI}: 38-39)\end{array}$ & $\begin{array}{c}31 \pm 4 \\
(\mathrm{CI}: 30-32)\end{array}$ & $\begin{array}{c}33 \pm 4 \\
(\mathrm{CI}: 32-34)\end{array}$ & $\begin{array}{c}30 \pm 4 \\
(\mathrm{CI}: 29-32)\end{array}$ & $\begin{array}{c}30 \pm 4 \\
(\mathrm{CI}: 29-31)\end{array}$ & $>0,001$ \\
\hline Thrombocyta & $(\mathrm{G} / \mathrm{l})$ & $\begin{array}{c}160 \pm 93 \\
(\mathrm{CI}: 136-185)\end{array}$ & $\begin{array}{c}163 \pm 78 \\
(\mathrm{CI}: 143-184)\end{array}$ & $\begin{array}{c}169 \pm 94 \\
(\mathrm{CI}: 145-193)\end{array}$ & $\begin{array}{c}130 \pm 77 \\
(\mathrm{CI}: 110-150)\end{array}$ & $\begin{array}{c}127 \pm 81 \\
(\mathrm{CI}: 106-148)\end{array}$ & 0,001 \\
\hline \multicolumn{8}{|c|}{ Térfogatalapú haemostasistartalékok } \\
\hline Paraméter & Egység & Tl (OLTx elött) & T2 (OLTx után) & T3 (12. óra) & T4 (24. óra) & T5 (48. óra) & p-érték \\
\hline & & átlag \pm szórás & átlag \pm szórás & átlag \pm szórás & átlag \pm szórás & átlag \pm szórás & \\
\hline Össztartalék (terület) & $\mathrm{L}^{2}$ & $\begin{array}{c}58 \pm 40 \\
(\mathrm{CI}: 48-69)\end{array}$ & $\begin{array}{c}24 \pm 29 \\
(\mathrm{CI}: 16-31)\end{array}$ & $\begin{array}{c}28 \pm 28 \\
(\mathrm{CI}: 21-36)\end{array}$ & $\begin{array}{c}35 \pm 29 \\
(\mathrm{CI}: 28-43)\end{array}$ & $\begin{array}{c}42 \pm 29 \\
(\mathrm{CI}: 34-49)\end{array}$ & $>0,001$ \\
\hline Fibrinogén (FI) & $\mathrm{ml}$ & $\begin{array}{c}4136 \pm 1729 \\
(\mathrm{CI}: 3685-4587)\end{array}$ & $\begin{array}{c}2598 \pm 1898 \\
(\mathrm{CI}: 2103-3093)\end{array}$ & $\begin{array}{c}4045 \pm 1868 \\
(\mathrm{CI}: 3558-4532)\end{array}$ & $\begin{array}{c}4741 \pm 2073 \\
(\mathrm{CI}: 4200-5281)\end{array}$ & $\begin{array}{c}4854 \pm 1831 \\
(\mathrm{CI}: 4377-5332)\end{array}$ & $>0,001$ \\
\hline Protrombin (FII) & $\mathrm{ml}$ & $\begin{array}{c}3855 \pm 1658 \\
(\mathrm{CI}: 3423-4287)\end{array}$ & $\begin{array}{c}2630 \pm 1632 \\
(\mathrm{CI}: 2204-3055)\end{array}$ & $\begin{array}{c}2880 \pm 1322 \\
(\mathrm{CI}: 2536-3225)\end{array}$ & $\begin{array}{c}2938 \pm 3392 \\
(\mathrm{CI}: 2054-3823)\end{array}$ & $\begin{array}{c}4410 \pm 1413 \\
(\mathrm{CI}: 4042-4778)\end{array}$ & $>0,001$ \\
\hline Kalcium (FIV) & $\mathrm{ml}$ & $\begin{array}{c}368 \pm 314 \\
(\mathrm{CI}: 286-450)\end{array}$ & $\begin{array}{c}-86 \pm 714 \\
(\mathrm{CI}:-272-100)\end{array}$ & $\begin{array}{c}-215 \pm 402 \\
(\mathrm{CI}:-320-110)\end{array}$ & $\begin{array}{c}-406 \pm 628 \\
(\mathrm{CI}:-569-242)\end{array}$ & $\begin{array}{c}-265 \pm 379 \\
(\mathrm{CI}:-363-166)\end{array}$ & $>0,001$ \\
\hline FV & $\mathrm{ml}$ & $\begin{array}{c}5087 \pm 1858 \\
(\mathrm{CI}: 4603-5571)\end{array}$ & $\begin{array}{c}2138 \pm 2418 \\
(\mathrm{CI}: 1508-2768)\end{array}$ & $\begin{array}{c}3108 \pm 2059 \\
(\mathrm{CI}: 2572-3645)\end{array}$ & $\begin{array}{c}4478 \pm 1820 \\
(\mathrm{CI}: 4003-4952)\end{array}$ & $\begin{array}{c}4772 \pm 2028 \\
(\mathrm{CI}: 4244-5301)\end{array}$ & $>0,001$ \\
\hline FVII & $\mathrm{ml}$ & $\begin{array}{c}4488 \pm 2120 \\
(\mathrm{CI}: 3935-5040)\end{array}$ & $\begin{array}{c}2552 \pm 2071 \\
(\mathrm{CI}: 2013-3092)\end{array}$ & $\begin{array}{c}2987 \pm 2264 \\
(\mathrm{CI}: 2397-3577)\end{array}$ & $\begin{array}{c}3722 \pm 2216 \\
(\mathrm{CI}: 3145-4300)\end{array}$ & $\begin{array}{c}3885 \pm 2035 \\
(\mathrm{CI}: 3355-4416)\end{array}$ & $>0,001$ \\
\hline $\mathrm{FX}$ & $\mathrm{ml}$ & $\begin{array}{c}4909 \pm 1930 \\
(\mathrm{CI}: 4406-5412)\end{array}$ & $\begin{array}{c}2135 \pm 2145 \\
(\mathrm{CI}: 1576-2694)\end{array}$ & $\begin{array}{c}2300 \pm 1631 \\
(\mathrm{CI}: 1875-2726)\end{array}$ & $\begin{array}{c}2897 \pm 1442 \\
(\mathrm{CI}: 2522-3273)\end{array}$ & $\begin{array}{c}3324 \pm 1692 \\
(\mathrm{CI}: 2883-3765)\end{array}$ & $>0,001$ \\
\hline FXIII & $\mathrm{ml}$ & $\begin{array}{c}3333 \pm 1781 \\
(\mathrm{CI}: 2869-3797)\end{array}$ & $\begin{array}{c}2175 \pm 1843 \\
(\mathrm{CI}: 1694-2655)\end{array}$ & $\begin{array}{c}1576 \pm 1436 \\
(\mathrm{CI}: 1202-1951)\end{array}$ & $\begin{array}{c}802 \pm 1460 \\
(\mathrm{CI}: 422-1183)\end{array}$ & $\begin{array}{c}814 \pm 1332 \\
(\mathrm{CI}: 467-1161)\end{array}$ & $>0,001$ \\
\hline AT-III & $\mathrm{ml}$ & $\begin{array}{c}3030 \pm 1974 \\
(\mathrm{CI}: 2515-3545)\end{array}$ & $\begin{array}{c}1240 \pm 2062 \\
(\mathrm{CI}: 703-1778)\end{array}$ & $\begin{array}{c}2784 \pm 1826 \\
(\mathrm{CI}: 2308-3260)\end{array}$ & $\begin{array}{c}3645 \pm 1330 \\
(\mathrm{CI}: 3298-3992)\end{array}$ & $\begin{array}{c}3707 \pm 1221 \\
(\mathrm{CI}: 3389-4025)\end{array}$ & $>0,001$ \\
\hline Hematokrit & $\mathrm{ml}$ & $\begin{array}{c}3273 \pm 2029 \\
(\mathrm{CI}: 2744-3802)\end{array}$ & $\begin{array}{c}888 \pm 839 \\
(\mathrm{CI}: 669-1107)\end{array}$ & $\begin{array}{c}1150 \pm 810 \\
(\mathrm{CI}: 939-1361)\end{array}$ & $\begin{array}{c}713 \pm 801 \\
(\mathrm{CI}: 504-922)\end{array}$ & $\begin{array}{c}555 \pm 702 \\
(\mathrm{CI}: 372-738)\end{array}$ & $>0,001$ \\
\hline Thrombocyta & $\mathrm{ml}$ & $\begin{array}{c}6668 \pm 1735 \\
(\mathrm{CI}: 6047-7288)\end{array}$ & $\begin{array}{c}6994 \pm 2164 \\
(\mathrm{CI}: 6430-7558)\end{array}$ & $\begin{array}{c}6856 \pm 2238 \\
(\mathrm{CI}: 6272-7439)\end{array}$ & $\begin{array}{c}5866 \pm 2307 \\
(\mathrm{CI}: 5265-6468)\end{array}$ & $\begin{array}{c}5761 \pm 2301 \\
(\mathrm{CI}: 5161-6361)\end{array}$ & 0,01 \\
\hline
\end{tabular}

ANOVA = (analysis of variance) varianciaanalízis; AT-III = antitrombin-III; CI = konfidenciaintervallum; FI = I-es faktor (fibrinogén); FII = II-es faktor (protrombin); FIV = IV-es faktor (kalcium); FV = V-ös faktor (proakcelerin - labilis faktor); FVII = VII-es faktor; FX = X-es faktor; FXIII = XIII-as faktor; OLTx $=$ ortotopikus májátültetés; $\mathrm{T} 1=$ májtranszplantáció előtt; T2 = mütét végén; T3 = a májátültetés után 12 órával; T4 = a májátültetés után 24 órával; T5 = a májátültetés után 48 órával 
3. táblázat $\mid$ A coagulatiósfaktor-szintek és a térfogatalapú faktorspecifikus haemostasistartalékok változásai OLTx előtt és végén ( $\Delta$ T1-T2); OLTx végén és a 24 órában $(\Delta \mathrm{T} 2-\mathrm{T} 4)$, valamint a 12. és a 48 . órában ( $\Delta \mathrm{T} 3-\mathrm{T} 5)$. A változókat a mérési idópontok között ismételt varianciaanalízissel (r-ANOVA) hasonlítottuk össze; az elemzés kétoldalas volt, $\alpha=0,05$ szignifikanciaszinttel

\begin{tabular}{|c|c|c|c|c|c|c|c|}
\hline \multicolumn{8}{|c|}{ A coagulatiósfaktor-szintek változásai } \\
\hline \multirow[t]{2}{*}{ Paraméter } & \multirow[t]{2}{*}{ Egység } & $\Delta \mathrm{T} 1-\mathrm{T} 2$ & \multirow[t]{2}{*}{ p-érték } & $\Delta \mathrm{T} 2-\mathrm{T} 4$ & \multirow[t]{2}{*}{ p-érték } & $\Delta \mathrm{T} 3-\mathrm{T} 5$ & \multirow[t]{2}{*}{ p-érték } \\
\hline & & átlag \pm szórás & & átlag \pm szórás & & átlag \pm szórás & \\
\hline$\Delta$ Fibrinogén $(\mathrm{FI})$ & $\mathrm{g} / 1$ & $\begin{array}{l}-1,2 \pm 0,6 \\
(\mathrm{CI}: 1-1,4)\end{array}$ & $>0,001$ & $\begin{array}{c}0,9 \pm 0,6 \\
(\mathrm{CI}: 0,7-1) \\
\end{array}$ & $>0,001$ & $\begin{array}{c}0,6 \pm 0,7 \\
(\mathrm{CI}: 0,3-0,7)\end{array}$ & $>0,001$ \\
\hline$\Delta$ Protrombin $(\mathrm{FII})$ & $\%$ & $\begin{array}{c}-26 \pm 14 \\
(\mathrm{CI}: 22-30)\end{array}$ & $>0,001$ & $\begin{array}{c}8 \pm 21 \\
(\mathrm{CI}: 2-13)\end{array}$ & $>0,001$ & $\begin{array}{c}20 \pm 16 \\
(\mathrm{CI}: 16-24) \\
\end{array}$ & $>0,001$ \\
\hline$\Delta$ Kalcium (FIV) & $\mathrm{mmol} / 1$ & $\begin{array}{c}-0,2 \pm 0,1 \\
(\mathrm{CI}: 0,1-0,2)\end{array}$ & $>0,001$ & $\begin{array}{c}-0,1 \pm 0,1 \\
(\mathrm{CI}: 0,05-0,2)\end{array}$ & 0,001 & $\begin{array}{c}-0,01 \pm 0,02 \\
(\mathrm{CI}: 0,05-0,08)\end{array}$ & n.s. $/ 0,6$ \\
\hline$\Delta \mathrm{FV}$ & $\%$ & $\begin{array}{c}-40 \pm 23 \\
(\mathrm{CI}: 34-47)\end{array}$ & $>0,001$ & $\begin{array}{c}28 \pm 26 \\
(\mathrm{CI}: 21-35)\end{array}$ & $>0,001$ & $\begin{array}{c}30 \pm 32 \\
(\mathrm{CI}: 22-39) \\
\end{array}$ & $>0,001$ \\
\hline$\Delta \mathrm{FVII}$ & $\%$ & $\begin{array}{c}-29 \pm 19 \\
(\mathrm{CI}: 24-34) \\
\end{array}$ & $>0,001$ & $\begin{array}{c}15 \pm 26 \\
(\mathrm{CI}: 8-21) \\
\end{array}$ & $>0,001$ & $\begin{array}{c}13 \pm 24 \\
(\mathrm{CI}: 7-19) \\
\end{array}$ & 0,001 \\
\hline$\Delta \mathrm{FX}$ & $\%$ & $\begin{array}{c}-39 \pm 22 \\
(\mathrm{CI}: 34-45)\end{array}$ & $>0,001$ & $\begin{array}{c}5,6 \pm 16 \\
(\mathrm{CI}: 1,4-10)\end{array}$ & 0,013 & $\begin{array}{c}12 \pm 19 \\
(\mathrm{CI}: 7-17)\end{array}$ & $>0,001$ \\
\hline$\Delta$ FXIII & $\%$ & $\begin{array}{c}-26 \pm 27 \\
(\mathrm{CI}: 19-34)\end{array}$ & $>0,001$ & $\begin{array}{c}-22 \pm 19 \\
(\mathrm{CI}:-17-27)\end{array}$ & $>0,001$ & $\begin{array}{c}-10 \pm 18 \\
(\mathrm{CI}:-5-16)\end{array}$ & $>0,001$ \\
\hline$\Delta$ AT-III & $\%$ & $\begin{array}{c}-35 \pm 27 \\
(\mathrm{CI}: 30-40) \\
\end{array}$ & $>0,001$ & $\begin{array}{c}-28 \pm 20 \\
(\mathrm{CI}:-21-35) \\
\end{array}$ & $>0,001$ & $\begin{array}{c}-13 \pm 10 \\
(\mathrm{CI}:-7-19)\end{array}$ & $>0,001$ \\
\hline$\Delta$ Hematokrit & $\%$ & $\begin{array}{c}-7 \pm 3 \\
(\mathrm{CI}: 6-8) \\
\end{array}$ & $>0,001$ & $\begin{array}{l}-0,8 \pm 1 \\
(\mathrm{CI}: 0-1)\end{array}$ & n.s. $/ 0,63$ & $\begin{array}{c}-3 \pm 10 \\
(\mathrm{CI}:-2-4) \\
\end{array}$ & $>0,001$ \\
\hline$\Delta$ Thrombocyta & $(\mathrm{G} / \mathrm{l})$ & $\begin{array}{c}3,4 \pm 53 \\
(\mathrm{CI}: 10-17)\end{array}$ & n.s. $/ 0,6$ & $\begin{array}{c}34 \pm 38 \\
(\mathrm{CI}:-23-43)\end{array}$ & $>0,001$ & $\begin{array}{c}-41 \pm 48 \\
(\mathrm{CI}: 24-58)\end{array}$ & $>0,001$ \\
\hline \multicolumn{8}{|c|}{ A térfogatalapú haemostasistartalékok változásai } \\
\hline \multirow[t]{2}{*}{ Paraméter } & \multirow[t]{2}{*}{ Egység } & $\Delta \mathrm{T} 1-\mathrm{T} 2$ & \multirow[t]{2}{*}{ p-érték } & $\Delta \mathrm{T} 2-\mathrm{T} 4$ & \multirow[t]{2}{*}{ p-érték } & $\Delta \mathrm{T} 3-\mathrm{T} 5$ & \multirow[t]{2}{*}{ p-érték } \\
\hline & & átlag \pm szórás & & átlag \pm szórás & & átlag \pm szórás & \\
\hline$\Delta$ Össztartalék (terület) & $\mathrm{L}^{2}$ & $\begin{array}{c}-34 \pm 25 \\
(\mathrm{CI}: 27-41) \\
\end{array}$ & $>0,001$ & $\begin{array}{c}11,6 \pm 16 \\
(\mathrm{CI}: 7-16)\end{array}$ & $>0,001$ & $\begin{array}{l}13,5 \pm 17 \\
(\mathrm{CI}: 9-18)\end{array}$ & $>0,001$ \\
\hline$\Delta$ Fibrinogén $(\mathrm{FI})$ & $\mathrm{ml}$ & $\begin{array}{c}-1537 \pm 1492 \\
(\mathrm{CI}:-1149-1926) \\
\end{array}$ & $>0,001$ & $\begin{array}{c}2142 \pm 1719 \\
(\mathrm{CI}: 1694-2590) \\
\end{array}$ & $>0,001$ & $\begin{array}{c}-808 \pm 2003 \\
(\mathrm{CI}: 286-1331) \\
\end{array}$ & $>0,001$ \\
\hline$\Delta$ Protrombin $(\mathrm{FII})$ & $\mathrm{ml}$ & $\begin{array}{c}-1225 \pm 1435 \\
(\mathrm{CI}:-851-1599) \\
\end{array}$ & $>0,001$ & $\begin{array}{c}308 \pm 3697 \\
(\mathrm{CI}: 654-1272) \\
\end{array}$ & n.s. $/ 0,5$ & $\begin{array}{c}1529 \pm 1077 \\
(\mathrm{CI}: 1248-1810)\end{array}$ & $>0,001$ \\
\hline$\Delta$ Kalcium (FIV) & $\mathrm{ml}$ & $\begin{array}{c}-454 \pm 689 \\
(\mathrm{CI}:-275-634) \\
\end{array}$ & $>0,001$ & $\begin{array}{c}-319 \pm 792 \\
(\mathrm{CI}:-113-526) \\
\end{array}$ & 0,003 & $\begin{array}{c}-49 \pm 384 \\
(\mathrm{CI}:-51-149)\end{array}$ & n.s. $/ 0,3$ \\
\hline$\Delta \mathrm{FV}$ & $\mathrm{ml}$ & $\begin{array}{c}-2949 \pm 1941 \\
(\mathrm{CI}:-2443-3455)\end{array}$ & $>0,001$ & $\begin{array}{c}2339 \pm 2124 \\
(\mathrm{CI}:-1786-2893)\end{array}$ & $>0,001$ & $\begin{array}{c}1663 \pm 2688 \\
(\mathrm{CI}: 963-2364)\end{array}$ & $>0,001$ \\
\hline$\Delta$ FVII & $\mathrm{ml}$ & $\begin{array}{c}-1935 \pm 1373 \\
(\mathrm{CI}:-1577-2293) \\
\end{array}$ & $>0,001$ & $\begin{array}{c}1170 \pm 2277 \\
(\mathrm{CI}: 576-1763)\end{array}$ & $>0,001$ & $\begin{array}{c}898 \pm 2222 \\
(\mathrm{CI}: 319-1477) \\
\end{array}$ & 0,003 \\
\hline$\Delta \mathrm{FX}$ & $\mathrm{ml}$ & $\begin{array}{c}-2774 \pm 1550 \\
(\mathrm{CI}:-2370-3178) \\
\end{array}$ & $>0,001$ & $\begin{array}{c}762 \pm 1617 \\
(\mathrm{CI}: 341-1184) \\
\end{array}$ & 0,001 & $\begin{array}{c}1023 \pm 1945 \\
(\mathrm{CI}: 516-1530) \\
\end{array}$ & $>0,001$ \\
\hline$\Delta$ FXIII & $\mathrm{ml}$ & $\begin{array}{c}-1158 \pm 1592 \\
(\mathrm{CI}:-743-1573) \\
\end{array}$ & $>0,001$ & $\begin{array}{c}-1372 \pm 1403 \\
(\mathrm{CI}:-1006-1738) \\
\end{array}$ & $>0,001$ & $\begin{array}{c}-762 \pm 1292 \\
(\mathrm{CI}:-425-1099) \\
\end{array}$ & $>0,001$ \\
\hline$\Delta$ AT-III & $\mathrm{ml}$ & $\begin{array}{c}-1789 \pm 1761 \\
(\mathrm{CI}:-1330-2248)\end{array}$ & $>0,001$ & $\begin{array}{c}2404 \pm 2214 \\
(\mathrm{CI}: 1827-2981)\end{array}$ & $>0,001$ & $\begin{array}{c}923 \pm 2161 \\
(\mathrm{CI}: 359-1486)\end{array}$ & 0,002 \\
\hline$\Delta$ Hematokrit & $\mathrm{ml}$ & $\begin{array}{c}-2384 \pm 2005 \\
(\mathrm{CI}:-1861-2907) \\
\end{array}$ & $>0,001$ & $\begin{array}{c}-175 \pm 633 \\
(\mathrm{CI}:-10-340) \\
\end{array}$ & 0,04 & $\begin{array}{c}-595 \pm 764 \\
(\mathrm{CI}:-395-794) \\
\end{array}$ & $>0,001$ \\
\hline$\Delta$ Thrombocyta & $\mathrm{ml}$ & $\begin{array}{c}326 \pm 997 \\
(\mathrm{CI}: 66-586) \\
\end{array}$ & 0,015 & $\begin{array}{c}-1127 \pm 1448 \\
(\mathrm{CI}:-750-1505) \\
\end{array}$ & $>0,001$ & $\begin{array}{c}-1094 \pm 1260 \\
(\mathrm{CI}:-766-1423) \\
\end{array}$ & $>0,001$ \\
\hline
\end{tabular}

AT-III = antitrombin-III; CI = konfidenciaintervallum; FI = I-es faktor (fibrinogén); FII = II-es faktor (protrombin); FIV = IV-es faktor (kalcium); $\mathrm{FV}=\mathrm{V}$-ös faktor (proakcelerin - labilis faktor); FVII = VII-es faktor; FX = X-es faktor; FXIII = XIII-as faktor; n.s. = nem szignifikáns; OLTx = ortotopikus májátülttetés; T1 = májtranszplantáció előtt; T2 = mútét végén; T3 = a májátültetés után 12 órával; T4=a májátülttetés után 24 órával; T5 = a májátültetés után 48 órával 
4. táblázat | Trombelasztográfiai paraméterek májtranszplantáció előtt és után. A változókat a mérési pontok között (T1-T2) ismételt varianciaanalízissel (r-ANOVA) hasonlítottuk össze; az elemzés kétoldalas volt, $\alpha=0,05$ szignifikanciaszinttel

\begin{tabular}{|c|c|c|c|c|}
\hline \multicolumn{5}{|c|}{ TEG-paraméterek } \\
\hline \multirow[t]{2}{*}{$\begin{array}{l}\text { TEG- } \\
\text { paraméterek }\end{array}$} & \multirow[t]{2}{*}{ Egység } & $\begin{array}{c}\text { Tl } \\
\text { (OLTx előtt) }\end{array}$ & $\begin{array}{c}\text { T2 } \\
\text { (OLTx után) }\end{array}$ & \multirow[t]{2}{*}{ p-érték } \\
\hline & & átlag \pm szórás & átlag \pm szórás & \\
\hline $\mathrm{R}$ & perc & $\begin{array}{c}5,9 \pm 3 \\
(\text { CI: } 5-6)\end{array}$ & $\begin{array}{c}6,8 \pm 4 \\
(\mathrm{CI}: 6-8)\end{array}$ & n.s. $/ 0,3$ \\
\hline $\mathrm{K}$ & perc & $\begin{array}{c}1,7 \pm 1 \\
(\mathrm{CI}: 1,5-2)\end{array}$ & $\begin{array}{c}2,3 \pm 2 \\
(\mathrm{CI}: 2-3)\end{array}$ & 0,01 \\
\hline MA & $\mathrm{mm}$ & $\begin{array}{c}67 \pm 8 \\
(\mathrm{CI}: 65-69)\end{array}$ & $\begin{array}{c}63 \pm 9 \\
(\mathrm{CI}: 60-65)\end{array}$ & 0,02 \\
\hline Ly 60 & $\%$ & $\begin{array}{c}5,8 \pm 5 \\
(\mathrm{CI}: 4-7)\end{array}$ & $\begin{array}{c}3,4 \pm 4 \\
(\mathrm{CI}: 2-5)\end{array}$ & 0,08 \\
\hline
\end{tabular}

$\mathrm{CI}=$ konfidenciaintervallum; $\mathrm{K}$ = kinetikai idő; Ly 60 = százalékos fibrinolízis 60 perc alatt; MA = maximális amplitúdó; n.s. = nem szignifikáns; OLTx = ortotopikus májátültetés; $\mathrm{R}=$ reakcióidő; TEG = trombelasztográfia

és ascites) a 12 . óráig $36 \pm 165 \mathrm{ml}$, a 24 . óráig $59 \pm 137$ $\mathrm{ml}$, míg a 48 . óráig $209 \pm 525 \mathrm{ml}$ volt. Az összbevitel a 12 . óráig $2650 \pm 1160 \mathrm{ml}$, a 24 . óráig $3198 \pm 1264 \mathrm{ml}$, míg a 48 . óráig $2823 \pm 1473 \mathrm{ml}$, a posztoperatív folyadékegyensúly pedig a 12 . óráig $533 \pm 1059 \mathrm{ml}$, a 24 . óráig $719 \pm 1065 \mathrm{ml}$ és a 48 . óráig $201 \pm 1336 \mathrm{ml}$ volt.

A kutatási protokollnak megfelelően az intraoperatív vérzés kompenzálására egyik betegnél sem volt szükség vörösvérsejt-szuszpenzióra, friss fagyasztott plazmára, thrombocytára vagy véralvadási faktor (fibrinogén, protrombinkomplex) pótlására. A mưtét végére a coagulatiósfaktor-szintek szignifikánsan, 26-40\%-kal csökkentek $(\mathrm{p}<0,001)$. A transzplantáció után az első 24 órában (T2-T4) a leghamarabb a fibrinogénszint nőtt $(\mathrm{p}<0,001)$.

A II-es, az V-ös, a VII-es és a X-es faktor szintje 12 30\%-kal emelkedett T3 és T5 között $(\mathrm{p}<0,001)$ (2. és 3. táblázat). A thrombocytaszám 36 betegnél növekedett a májtranszplantáció végére $(\mathrm{p}<0,04)$. A trombelasztográfiás vizsgálatokon a véralvadási idő minimális növekedése, a rögkinetika, a vérrögamplitúdó enyhe csökkenése volt megfigyelhető, azonban minden paraméter a normáltartományban maradt az OLTx (T1-T2) végén is (4. táblázat).

A Gross-metódus alapján meghatározott térfogatalapú preoperatív haemostasistartalékok közül a thrombocyta, az V-ös, a X-es és a VII-es faktor és a fibrinogén a teljes keringő vértérfogathoz viszonyítva 75\%-nál nagyobb tartalékot mutatott. A keringő vértérfogat 50\%ánál nagyobb tartalékkal a II-es és a XIII-as faktor, az AT-III és a hematokrit rendelkezett (2. táblázat). Az alvadásspecifikus tartalékok szignifikánsan csökkentek a májtranszplantáció végére. A kiindulási értékek felére csökkent a protrombináz (V-ös, X-es faktor) és a hematokrit. A vértérfogat 1/3-ának megfelelő tartalékcsökke- nést találtunk a VII-es faktor, a fibrinogén és az AT-III esetében, míg 25\%-os csökkenést tapasztaltunk a protrombin és a XIII-as faktor esetében. A thrombocytaalapú tartalékok viszont nem változtak az OLTx végére (2. és 3. táblázat). A térfogatalapú haemostasistartalékok a májátültetés után követték a faktorszinteket. A fibrinogén tartaléka 24 óra alatt rendeződött $(\mathrm{p}<0,001)$. A II-es, az V-ös, a VII-es és a X-es faktor tartalékai lassabban emelkedtek, és az első 48 óra (T3-T5) alatt csak megközelítették a kiindulási értékeket $(\mathrm{p}<0,001)$ (4. ábra).

A görbe alatti területből kiszámított haemostasis-össztartalék $58 \pm 40 \mathrm{~L}^{2}$-ről $61 \%$-kal csökkent a mütét végére (T1-T2; p<0,001), ezt követően növekedett, és a posztoperatív második napra (T5) elérte a kiindulási érték 88\%-át (4. ábra). A portalis hypertensio súlyossága szerint vizsgálva a kiindulási össztartalék esetében a ChildPugh A csoporthoz viszonyítva a dekompenzált ChildPugh B csoportnál 36\%-kal és a Child-Pugh C csoportnál 41\%-kal alacsonyabb értékek voltak megfigyelhetók. A posztoperatív második napra azonban az alvadásspecifikus tartalékok közötti különbség már nem volt szignifikáns (5. ábra).

\section{Megbeszélés}

A sebészeti technika fejlődése mellett az aneszteziológia és az intenzív terápia is dinamikusan elörehaladt az elmúlt évtizedekben $[3,12]$. Ezáltal megnövekedett a vérmentes sebészeti beavatkozások száma. A coagulopathiás vérzés kockázata háromféleképpen definiálható: konvencionális faktorszintekkel és thrombocytaszámmal, viszkoelasztikus tesztekkel és térfogatalapú haemostasistartalékokkal, azaz alvadásifaktor-specifikus vérveszteséggel. Központunkban 175, vérkészítménymentes beavatkozás történt, 59 májtranszplantáció során alvadásifaktor-készítmény alkalmazására sem volt szükség.

Vizsgálatunkban a betegek alacsony MELD-pontszámmal és enyhe extrahepaticus diszfunkciókkal rendelkeztek a mútét előtt. A cirrhosis oka többnyire primer szklerotizáló cholangitis, hepatitis C-vírus-fertőzés és autoimmun hepatitis volt. A végstádiumú májelégtelenség ezen formáiban általában jó szintetikus funkciót találtunk. Ezen betegcsoport vizsgálatának első fő megállapítása, hogy a fibrinogénszint májátültetés során átlagosan 1,2 g/l-rel csökken. A fibrinogénszint hasonló csökkenését $1 \mathrm{~g} / \mathrm{l}$-re Costa és mtsai is megfigyelték korábban, de ez vérzéssel és vérkészítmény igényével járt együtt [13]. Betegeinknél a vér viszkoelasztikus tulajdonságai, a transzplantáció végi TEG-eredmények jól kiegyensúlyozott alvadást mutattak, $40 \mathrm{~mm}$-nél nagyobb vérrög (MA) volt mérhető minden esetben. Véleményünk szerint 36 esetben a fibrinogénszint csökkenését kompenzálta a vérlemezkék számának növekedése, ami magyarázhatja a coagulopathia hiányát $[14,15]$. Eredményeink megerősítik Coakley és Sabate megfigyeléseit, amelyek szerint ha a perioperatív vérrög mérete kisebb, 


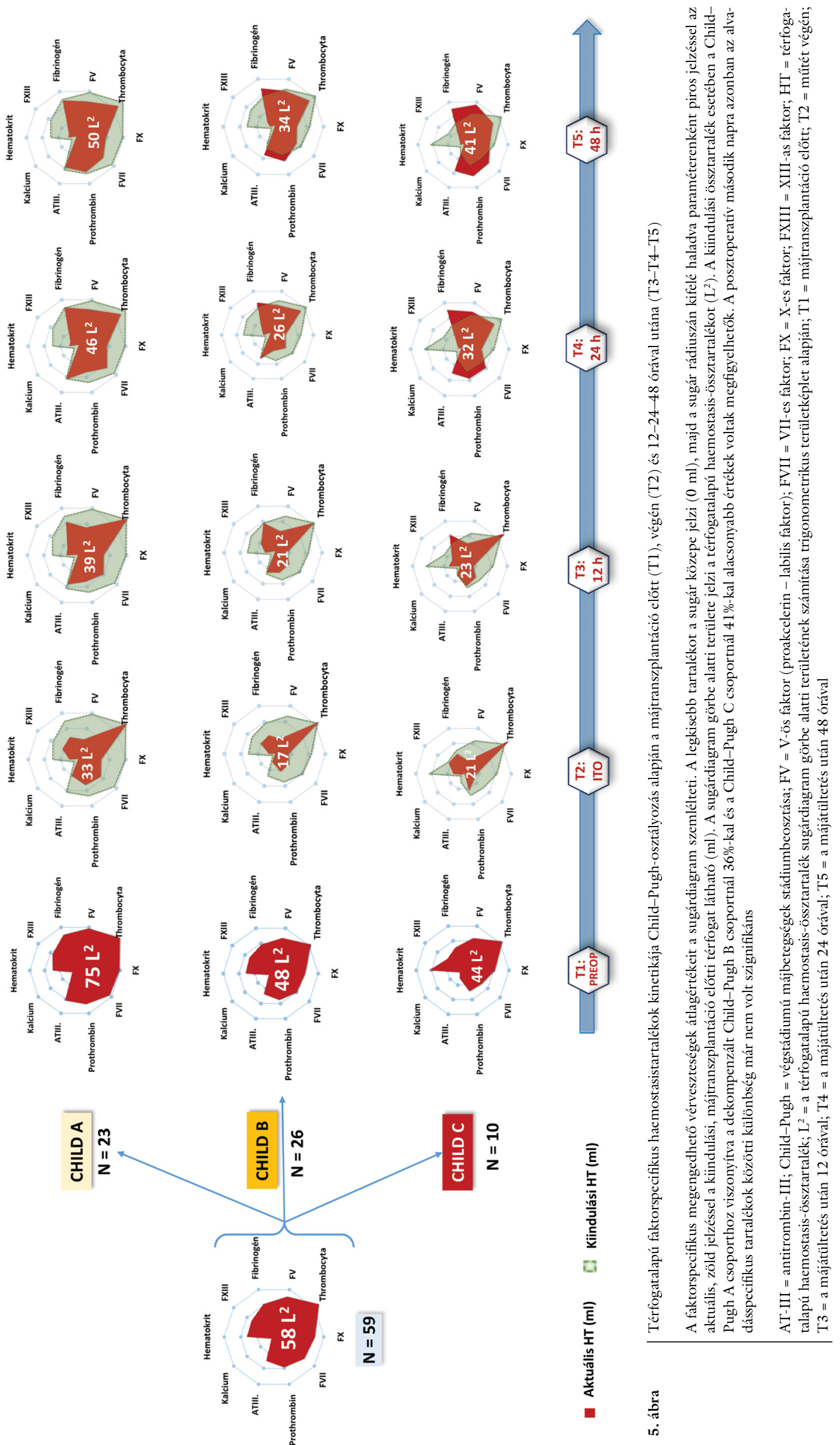


mint 35-40 mm, az a coagulopathiás vérzés veszélyét növeli $[6,7]$.

Gyakorlati szempontból elmondható: amennyiben a preoperatív végstádiumú májbetegséggel kapcsolatos fibrinogénszint $2,2 \mathrm{~g} / \mathrm{l}$ felett van, nem várható coagulopathiás vérzés, valamint ha a pozitív folyadékegyensúly elkerülhető, akkor sikeres vérkészítménymentes májátültetés várható.

A haemostasis térfogatalapú tartalékának követése nem szokványos megközelítése a nagy vérigényú mútéteknek, ezen belül a májtranszplantációnak. Ezen megközelítés nem helyettesíti a laboratóriumi vagy viszkoelasztikus tesztek általi haemostasismonitorozást, hanem kiegészíti azt, mert dinamikus, megnövelve ezáltal a betegbiztonságot. Ezáltal a transzplantációs team a konvencionális vagy viszkoelasztikus tesztek elvégzése nélkül is érzékeli a specifikus tartalékok csökkenését. Amikor a mütét alatti veszteség megközelíti a legkisebb térfogati tartalékkal rendelkező alvadásifaktor-tartalékot, akkor a leggyengébb láncszem elve alapján specifikusan, időben beavatkozhat, majd a terápia eredményességét konvencionálisan vagy viszkoelasztikus módszerrel ellenőrizheti. Az intraoperatív vérzés, consumptio, minimális dilutio okozta fibrinogén- és egyéb faktorszintcsökkenés szignifikánsan, lényegében a felére csökkentette az alvadásifaktor-specifikus vérveszteségi térfogatokat vizsgálatunkban, és bár egyes faktorszintek megközelítették a coagulopathiás haemostasistartalék térfogati értékeit, azokat nem haladták meg [16]. Fontos megjegyezni: tapasztalt sebészeti háttér garantálta, hogy minden vizsgált esetben a teljes vérveszteség $1174 \pm 490 \mathrm{ml}$-nél nem volt nagyobb „cell saver” használata nélkül. A vér nélküli májátültetést Massicotte és mtsai is vizsgálták; tanulmányaikban az intraoperatív vérveszteség kevesebb volt, mint $820 \mathrm{ml}$, amit ők a portalis hypertensio és a CVP eredményes csökkentésével és „cell saver” használatával értek el [17]. Vizsgálatunkban mi is az alacsony CVP-re, normovolaemiára törekedtünk szoros hemodinamikai megfigyelés mellett. A folyadékegyensúly óránkénti ellenőrzésének célja a coagulatiós faktorok hígításának elkerülése volt. A graftreperfusio által okozott vasomotoros változásokat noradrenalinnal kezeltük. Bizonyos esetekben a térfogat-szubsztitúciót - a folyadék túlterhelésének elkerülése érdekében - vasoactiv támogatással kombináltuk szoros hemodinamikai monitorizálás mellett, ennek megfelelően betegeinknél $610 \pm 896 \mathrm{ml}$ pozitív folyadékegyensúly volt megfigyelhető.

$\mathrm{Az}$ intraoperatív hypocalcaemiát Jawan és mtsai is megfigyelték vérmentes májtranszplantációk során. Eredményeik azt sugallják, hogy ha a transzfúzió elkerülése révén az exogén citrátterhelést kizárjuk, a haemodilutio, valamint az ascites- és folyadékvesztés pótlására használt $5 \%$ albumin alkalmazása során továbbra is fennáll a hypocalcaemia kockázata. Az általunk vizsgált betegcsoportban is jellemző volt a kalcium (FIV) kis tartaléka, amelyet intraoperatív körülmények között folyamatos perfúzorban történő pótlással, majd igény szerinti bolusadagolással korrigáltunk [18].

A vizsgálat második fó megállapítása a fibrinogénszint $0,9 \mathrm{~g} / 1$-es növekedése volt az első posztoperatív nap végére, párhuzamosan a II-es, az V-ös, a VII-es és a X-es faktor szintjének növekedésével, amelyek 12-30\%-kal emelkedtek a második posztoperatív nap végére. Ezen eredmények együttesen jó graftfunkcióra utaltak. A beavatkozást igénylő alacsony posztoperatív fibrinogénszinteket Kirchner és mtsai is megfigyelték 110, vérmentes májtranszplantációnál, amely esetekben az aszpartát-aminotranszferáz (AST) $(1300 \mathrm{U} / \mathrm{l})$ és az alanin-aminotranszferáz (ALT) $(800 \mathrm{U} / \mathrm{l})$ magas szintje a májmúködés károsodására utalt. Vizsgálatunkban a beültetett graftok minőségét alacsonyabb donorrizikó-index és mérsékelt hideg- és melegischaemiás idők jellemezték [19]. Ehhez képest a megfigyelt betegcsoportunkban a citolízis minden esetben kevesebb mint $800 \mathrm{U} / 1$ volt. A fibrinogén, a protrombin és az V-ös, VII-es, X-es faktor mútét utáni alacsony szintje ellenére a posztoperatív vérzés hiánya azt sugallja, hogy a rendszer kiegyensúlyozott, de csökkentett tartalékkapacitással rendelkezik. Az alvadási faktorok „térfogatalapú” megközelítése jelezte a legkisebb térfogati tartalékkal rendelkező alvadási faktorokat, továbbá a tartalékok kinetikája jól követhető volt a májátültetés utáni korai fázisban, ami a transzplantáció utáni folyadékterápia tervezésében és kivitelezésében is segítséget nyújt a kezelőszemélyzetnek. Praktikusan, ha hemodinamikai alapon az aktuális tartaléknál nagyobb volumenterápiára van szükség, akkor az a coagulatiós faktor párhuzamos pótlásával kell, hogy történjen a dilutiós coagulopathia elkerülése végett, ezáltal növelve a betegbiztonságot [16].

A portalis hypertensio súlyosságát is követő ChildPugh-osztályozás szerint a betegek fele vascularisan dekompenzált volt, az 59-ból 10 beteg súlyosan. A térfogatalapú haemostasismegközelítés dinamikusan érzékelteti az alacsonyabb kiindulási faktorszintek veszélyét a portalis hypertensio jelenlétében.

\section{Következtetések}

Vizsgálatunk alapján elmondható, hogy a coagulatiósfaktor-szintek kinetikája a „pipajel” formáját követi vérkészítménymentes májtranszplantáció során. A viszkoelasztikus vizsgálatok az alvadásifaktor-szintek kinetikáját kiegészítve coagulopathiamentes rögnagyságot jeleztek, ami a vérlemezkék kompenzatorikus szerepére utal. A haemostasis térfogatalapú megközelítése dinamikusan jelzi a haemostasis aktuális tartalékát faktoronként, és segíti a kezelést a beteg egyéni igényeire adaptálni azáltal, hogy a „leggyengébb láncszemet” mutatja meg a rendszerben.

Ha a betegek preoperatív kiindulási fibrinogénszintje meghaladja a 2,2 g/l-t, nincs súlyos portalis hypertonia, semmiféle mútéti komplikáció nem várható, és ha a pozitív folyadékegyenleg elkerülhető, sikeres vérkészít- 
ménymentes transzplantáció várható. Ez azonban inkább fikció marad nehezebb mútéti körülmények között, magasabb (>35) MELD-pontszámmal rendelkező vagy idős betegek körében, valamint a hosszú várakozási listák esetében egyaránt.

A haemostasis nem szokványos, térfogatalapú megközelítése lehetővé teszi a nagyobb vérzési kockázatú sebészeti beavatkozások vérmentességét, ezáltal más perioperatív körülményekre is extrapolálható, akár a Jehova Tanúi gyülekezet betegei számára is.

Tanulmányunk megfelelt a helsinki deklaráció kritériumainak, így a Semmelweis Egyetem Regionális Etikai Bizottsága jóváhagyta (SE-TUKEB: 149/2016), továbbá a ClinicalTrials.gov-ban is bejegyzésre került (NCT03555383). Regisztrálva: 2018. június 13.

Anyagi támogatás: A közlemény megírása és a kapcsolódó kutatómunka anyagi támogatásban nem részesült.

Szerzôi munkamegosztás: R. K. T.: Irodalomkutatás, az adatok gyújtése és feldolgozása, statisztikai próbák kivitelezése, a publikáció szövegezése és szerkesztése. K. L., P. L., M. Z., Sz. J., I. S., M. T., S. A., Sz. T., Sz. M., T. Sz., T. G., T. Cs., F. B.: A kézirat kritikus áttekintése, véleményezése. K. P.: A kézirat kritikus áttekintése, véleményezése, angol nyelvű lektorálás. D. E.: A kézirat kritikus áttekintése, statisztikai próbák ellenőrzése, véleményezése. F. J.: Irodalomkutatás, a kézirat koncepciójának megalkotása, a publikáció szövegezése és szerkesztése, szakmai felügyelete. A cikk végleges változatát valamenynyi szerző elolvasta és jóváhagyta.

Érdekeltségek: A szerzőknek nincsenek érdekeltségeik.

\section{Irodalom}

[1] Jakab F. Milestones in liver surgey. [Mérföldkövek a máj sebészetében.] Orv Hetil. 2018; 159: 375-383. [Hungarian]

[2] Fazakas J, Smudla A. Anesthetics and intensive therapeutic aspects of liver transplantation. [A májátültetés aneszteziológiaiintenzív terápiás vonatkozásai.] Orv Hetil. 2018; 159: 18911897. [Hungarian]

[3] Wettstein D, Tóth SzJ, Máthé Z. New challenges of liver transplantation. [A májtranszplantáció új kihívásai.] Orv Hetil. 2019; 160: 1127-1135. [Hungarian]

[4] Kozek-Langenecker SA, Ahmed AB, Afshari A, et al. Management of severe perioperative bleeding: guidelines from the European Society of Anaesthesiology: first update 2016. Eur J Anaesthesiol. 2017; 34: 332-395.
[5] Bezinover D, Dirkmann D, Findlay J, et al. Perioperative coagulation management in liver transplant recipients. Transplantation 2018; 102: 578-592.

[6] Coakley M, Reddy K, Mackie I, et al. Transfusion triggers in orthotopic liver transplantation: a comparison of the thromboelastometry analyzer, the thromboelastogram, and conventional coagulation tests. J Cardiothorac Vasc Anesth. 2006; 20: 548-553.

[7] Sabate A, Blasi A, Costa M, et al. Assessment of rotational thromboelastometry for the prediction of red blood cell requirements in orthotopic liver transplantation. Minerva Anestesiol. 2018; 84: 447-454.

[8] Dötsch TM, Dirkmann D, Bezinover D, et al. Assessment of standard laboratory tests and rotational thromboelastometry for the prediction of postoperative bleeding in liver transplantation. Br J Anaesth. 2017; 119: 402-410.

[9] Gross J. Estimating allowable blood loss: corrected for dilution. Anesthesiology 1983; 58: 277-280.

[10] Gibon E, Courpied JP, Hamadouche M. Total joint replacement and blood loss: what is the best equation? Int Orthop. 2013; 37: 735-739.

[11] Sud S, Dwivedi D, Sawhney S, et al. Intraoperative error in estimation of blood loss due to change in the size of abdominal swab. Indian J Anaesth. 2018; 62: 822-824.

[12] Babik B, Fazakas J, Matusovits A, et al. Forced steps for making improvements in severe perioperative haemorrhage. [Lépéskényszerben - új feladatok az életveszélyes perioperatív vérzések ellátásában.] Orv Hetil. 2019; 160: 203-213. [Hungarian]

[13] Costa M, Dalmau A, Sabate M, et al. Low plasma fibrinogen levels and blood product transfusion in liver transplantation. Minerva Anestesiol. 2014; 80: 568-573.

[14] Niemann M, Lund A, Lunen TB, et al. Role of spleen and liver for enhanced hemostatic competence following administration of adrenaline to humans. Thromb Res. 2019; 176: 95-100.

[15] Coelho JC, Balbinot P, Nitsche R, et al. Change in platelet count in patients with hypersplenism subjected to liver transplantation. Arq Gastroenterol. 2011; 48: 175-178.

[16] Krzych LJ, Czempik PF. Association between standard laboratory and functional tests of coagulation in dilutional coagulopathy: an in vitro study. J Physiol Pharmacol. 2017; 68: 637-645.

[17] Massicotte L, Denault AY, Thibeault L, et al. Relationship between conventional coagulation tests and bleeding for 600 consecutive liver transplantations. Transplantation 2014; 98: el3el5.

[18] Jawan B, de Villa V, Luk HN, et al. Ionized calcium changes during living-donor liver transplantation in patients with and without administration of blood-bank products. Transpl Int. 2003; 16: 510-514.

[19] Kirchner C, Dirkmann D, Treckmann JW, et al. Coagulation management with factor concentrates in liver transplantation: a single-center experience. Transfusion 2014; 54: 2760-2768.

(Rengeiné Kiss Tímea,

Budapest, Baross u. 23-25., 1083

e-mail: rengeine_kiss.timea@med.semmelweis-univ.hu)

A cikk a Creative Commons Attribution 4.0 International License (https://creativecommons.org/licenses/by/4.0/) feltételei szerint publikált Open Access közlemény, melynek szellemében a cikk bármilyen médiumban szabadon felhasználható, megosztható és újraközölhetö, feltéve, hogy az eredeti szerző és a közlés helye, illetve a CC License linkje és az esetlegesen végrehajtott módosítások feltüntetésre kerülnek. (SID_1) 